\title{
RESULTADO PARCIAL DO XENODIAGNÓSTICO REALIZADO EM UM GRUPO DE PACIENTES SEROLÖGICAMENTE POSITIIVOS PA- RA A DOENÇA DE CHAGAS E INTERNADOS NO HOSPITAL SÃO PEDRO (DE ALIENADOS), EM PÔRTO ALEGRE, RIO GRANDE DO SUL, BRASIL
}

\begin{abstract}
Darcy Farias Lima * Netvton Veves da Silva * João Francisco Cardoso dos Santos * Ayrton Guaycurus Zingano* Oscar Miranda Fróes * João Aluizio Braga Chaer **
\end{abstract}

\begin{abstract}
Exames sorológicos de Imunofluorescéncia, Fixação do Complemento e Hemoaglutinacão para a Doenca de Chagas foram realizados em 1609 pacientes. Em 154 casos, as provas foram positivas, com um indice percentual de $9,57 \%$. Posteriormente, 50 casos sorologicamente positivos foram submetidos ao xenodiagnóstico. Os xeno-positivos revelaram um indice de 5,35\% sôbre o tolal de casos examinados e de 56\% sôbre os soroiogicamente positivos. Chama-se a atenç̃̃o para a alta incidència de chnagásicos no Hospital são Pedro, ao lado de outras consideracóes.
\end{abstract}

As informações - contidas na presente comunicação e obtidas ncs laboratórios da cadeira de Parasitologia da Faculdade de Medicina da U.F.R.G.S., do Instituto de Pesquisas Biológicas (IPB) do R:o Grande do Sul e do Instituto de Diagnóstico y Investigación de la Enfermedad de Chagas (Dr. Mario Facala Chaben) de Buenos Aires - são parte de um plano mais amplo de pesquisa que visa ao estrdo da eficácia e da tolerancia do derivado nitrofurânico Bayer 2502 na forma crônica do Mal de Chagas.

O Hospital São Pedro aiberga cêrca de 4.0อ0 pacientes internados.

Dêsse total -- até a data de 24-11-1969 - em 1609 doentes escolhidos ao acaso, foram praticadas as reacooes scrológicas de hemoaglutinação, imunofluorescência e fi- xação do complemento (Machado-Guerreiro).

Os casos positivos foram posteriormente submetidos ao xenodiagnóstico, tcmandose o cuidado de admitir sòmente os que se mostraram positivos nas três reaçôes simultâneamente.

Fxecutaram-se as reações sorológicas $\mathrm{em}$ duplicatas, por medida de segurança, nos laboratórios co I.P.B. e do Insitituto $\mathrm{Dr}$. Mario Tatala, para pcsterior confronto dos resultados. Pelas mesmas razões, as provas de xenodiagnóstico se realizaram também cm dupicata, na cátedra de Parasitologia da Fac. Med. da U.F.R.G.S. e no Instituto Dr. Nario Fatala.

Dos crivos sorológicos acima apontados, resuiteram 154 casos positivos, indicando uma incidencia de $9,57 \%$ de positividade.

* Da Catedra de Parasitologia da Fac. Med. da U.F.P.G.S.

* Do Instituto de Fesquisas Biolóricas do Plo Grande do Sul.

* * Do Instituto Nacional de Previdência Social. Recebido para publicaçâo em 20-7-70. 
XENODIAGNÓSTICO

$$
\text { P. Alegre }
$$

$\mathrm{N}^{\circ}$

875

418

100

69

407

127

468

645

208

800

120

345

280

323

577

490

305

785

540

295

549

788

317

508

94

670

197

114
Paciente

J. L. A.

J. F. P. L.

A. P. F.

J. S.

J. A, F

J. S. M.

A. G.

B. P. S.

A. C. F

A. T. S.

A. S. P.

P. M.

V. N.

G. F.

C. $B$.

A. B. D.

S. M. 11985

E. A.

A. A. Z.

O. V. L.

C. $R$.

F. S.

B. $O$.

A. A.

A. $R$.

C. A. F.

N. A.

A.R. F.
A $B \quad C$ D
E F G H

B. Aires

$0+00$

$\begin{array}{llll}0 & 0 & 0 & 0\end{array}$

$\begin{array}{llll}0 & 0 & 0 & 0\end{array}$

$+000$

$00+0$

$\begin{array}{llll}0 & 0 & 0 & 0\end{array}$

$00+0$

$\begin{array}{llll}0 & 0 & 0 & 0\end{array}$

$\begin{array}{llll}0 & 0 & 0 & -1\end{array}$

$\begin{array}{llll}0 & 0 & 0 & 0\end{array}$

$\begin{array}{llll}0 & 0 & 0 & 0\end{array}$

$+00+$

$\begin{array}{llll}0 & 0 & 0 & 0\end{array}$

$\begin{array}{llll}0 & 0 & 0 & 0\end{array}$

$++00$

$0+++$

$00+0$

$00+0$

$00++$

$00+0$

$0+00$

$\begin{array}{lll}0 & 0 & +\end{array}$

$0+++$

$\begin{array}{llll}0 & 0 & 0 & +\end{array}$

$++0+$

$0+++$

$0+0+$

$+++$

$\begin{array}{ll}0 & 0\end{array}+$

$++0+$

$0+++$

$+++$

$+t+$

$+00+$

$00++$

$+0++$

$++t+$

$++0+$

$+0++$

$+t+$

$++0+$

$+++$

$++t$

$++\frac{1}{s}+$

$++t+$ 
Dêsse grupo - tomando-se o critério de eliminar os indivíduos com mais de sessen. ta anos e os psicopatas que, por óbvias razões reagiam à aplicarão dos triatomídeos - selecionamcs 50 pacientes para a prova xenodiagnóstica. $\mathrm{C}$ exame acusou 28 casos positivos, com um índice de $56 \%$ sôbre os sorològicamente positivos e de $5,35 \%$ sôbre o total dos casos examinados.

Nas provas de xenodiagnóstico seguiu-se o critério propugnado por Schenone e Cols., que recomenda o uso de um grande número de triatomas, principalmente nas avaliações de métodos terapêuticos na infecção chagásica crônica.

88 triatomas, nas fases de ninfa de $3^{\text {o }}$ e 4ํ estágio foram aplicados em cada paciente, em caixas de 11, quatro das quais na face externa de cada braço, durante trinta minutos.

Os resultados acima relatados referemse à primeira leitura regulamentar, feita após trinta dias da aplicação dos barbeircs, realizada dentro da seguinte orientação:

a) Exonerava-se o conteúdo de cada caixa em um copo de Becker, no qual eram contados os barbeiros, anotado o número de mortos se houvesse e desprezadas as capas resultantes de ecdises;

b) Em uma placa de pcrcelana escavada realizavam-se dois "pools" com solução tampão, relativos cada um dêles às fezes da metade cio número de triatomas existentes na caixa;

c) De cada "pool" preparavam-se duas lâminas, as quais eram examinadas por dois técnicos distintos;

d) Os casos positivos sempre foram confirmados por mais de um técnico.

Com os dados obtidos queremos:

1) Chamar a atençãc para a alta incidência de chagásicos no nosocômio em aprêço;

2) Reafirmar a validez do critério técnico preconizado por Schenone e Cols, na realização do xenodiagnóstico, critério êsse que ncs possibilita um aumento de probabilidade no diagnóstico da infecção chagásica crônica;

3) Sugerir um estudo mais acurado no que tange à procedência geográfica dos pacientes infectados, pois, mesmo a uma visão superficial, ficou bastante evidente que bom nûmero de chagásiccs provinha de localidades situadas na margem esquerda do rio Uruguai;

4) Apontar a conveniência de se proceder a uma investigação no que toca à existência do transmissor no Hospital são Pedro e imediações;

5) Chamar a atenção para uma hipótese de trabalho que seria a relação de causa e efeitc entre o Trypanosoma cruzi e certas psicopatias.

\section{S U M M A Y}

Serological tests of fluorescent antibodies, hemagglutination, and complement fixation fo Chagas' disease were performed in 1609 cases. In 154 cases the three thests were positives, with a rate of $9,57 \%$. Furtherly 50 serologioally positive patients were examined by means of xenodiagnosis. Rates found were of $56 \%$ upon the number of serologically positive and of 5,35\% upon 1609 persons examined. Attention is called on the high incidence of Chagas' disease at the Hospital São Pedro, besides others remarks.

\section{REFERENCIA}

SCHENONE H., ALFARO E., REYES H. Y TAUCHER E. - Valor del Xenodiganostico en la Infeccion Chagasica Cronica. Bol. Chile. Parasit. 23: 149-154, 1968. 
(Continuação da página 366,

Art. 6. - O parecer da Comissão Julgadora deverá ser emitido até o início do Congresso da Sociedade Brasileira de Medicina Tropical nos anos pares, quando 0 prêmio será solenemente entregue ao vencedor. A primeira entrega de prêmio será em 1970 .

Art. $7^{\circ}$ - Os casos omissos neste re- guiamento serão resolvidos pelo Diretor do Instituto Brasileiro de Tropicologia Médica em conformidade com o Presidente da Sociedade Brasileira de Medicina Tropical e se for o caso com a Firma Patrocinadora e ao candidato não caberá nenhum recurso ao parecer da Comissão Julgadora ou de seu Presidente. 